\title{
Trade Measures to Prevent Illegal Fishing and the WTO: An Analysis of the Settled Faroe Islands Dispute
}

\author{
KATHLEEN AULD * \\ University of Cape Town
}

\begin{abstract}
There has been increasing litigation in the WTO on environmental issues in recent years, much of it about fishing. Two cases, Chile-Swordfish and Faroes-Herring, brought to light the potential for conflict between trade and fisheries law through the imposition of port state measures by WTO members to prevent illegal, unreported, and unregulated (IUU) fishing, although both cases were settled before reaching Panel stage. Port state measures aim to combat IUU fishing by allowing countries to close their ports to IUU fish. This includes using trade measures and trade-related measures, such as import bans and transshipment bans, which may violate WTO law. The potential for conflict is even more acute now that the Port State Measures Agreement (PSMA) has come into force. This paper takes as its study Faroes-Herring, where the Faroes challenged certain EU regulations aimed at preventing IUU fishing through the use of port state measures. It examines whether these regulations comply with WTO law, and makes recommendations as to how a Panel or Appellate Body can resolve this type of dispute. Specifically, it focuses on ways in which international fisheries law can be incorporated in this process to avoid a conflict between international trade and fisheries law.
\end{abstract}

\section{Introduction}

The Faroes-Herring dispute ${ }^{1}$ arose because of disagreement about the quota allocation for Atlanto-Scandian herring (hereafter called herring) within the North-East Atlantic Fisheries Commission (NEAFC), a regional fisheries management organization (RFMO) set up to preserve and manage certain fish stocks, including herring.

In order to maintain the herring stock in the North-East Atlantic at sustainable levels, the five members of NEAFC - the EU, Faroes, Iceland, Norway, and the Russian Federation - have a long-term fisheries management plan for herring (the herring management plan). ${ }^{2}$

*Email: aldkat003@gmail.com; aldkat003@myuct.ac.za

1 WTO, EU-Measures on Atlanto-Scandian Herring: Request for Consultations by Denmark in Respect of the Faroe Islands, 7 November 2013, WT/DS469/1.

2 Pelagic AC, Coastal States Management Plan Atlanto-Scandian Herring 1999 (1999), http://www. pelagic-ac.org/media/pdf/Atlanto-Scandian\%20herring\%201999.pdf (accessed 15 February 2017). For 
Under the herring management plan, the members of NEAFC agree on a total allowable catch for herring based on the recommendations of the International Council for the Exploration of Seas (ICES), an inter-governmental organization (IGO) set up to provide scientific advice on the sustainable use of marine ecosystems. The NEAFC members meet once a year to determine how the total allowable catch should be allocated amongst themselves for the following year. In 2013, however, the Faroes set a unilateral catch far above the share allocated to it in the 2012 consultations. The Faroes had withdrawn from these consultations prior to the making of the allocation by the other NEAFC members.

The EU has passed a number of regulations through which it attempts to prevent illegal, unreported, and unregulated (IUU) fishing, not only in its own waters but also in those of other states. These include its IUU Regulation ${ }^{3}$ and Shared Stocks Regulation, ${ }^{4}$ which impose different types of port state measures on IUU fishing offenders. The Shared Stocks Regulation requires the EU to use port state measures against third countries that allow non-sustainable fishing of common stocks, which that country has a duty to conserve and manage through cooperation with other states. ${ }^{5}$

After the Faroes set its unilateral catch quota, the EU used the Shared Stocks Regulation to ban imports of herring and the associated species of Northeast Atlantic Mackerel (hereafter mackerel), from entering the EU from the Faroes. The EU further restricted access to its ports, including for transshipment purposes, ${ }^{6}$ for Faroese vessels, and vessels authorized by the Faroes that were engaged in the herring and mackerel fisheries or transporting products containing herring and mackerel. The EU took this action after identifying the Faroes as a country allowing non-sustainable fishing (NSF), alleging that it had failed to comply with the management measures for herring decided by the NEAFC contracting parties. ${ }^{7}$

The Faroes then requested consultations with the $\mathrm{EU}^{8}$ under the WTO's Dispute Settlement Understanding (DSU). ${ }^{9}$ It argued that the Shared Stocks Regulation and another regulation, the Implementing Regulation, ${ }^{10}$ which the EU promulgated to impose its measures against the Faroes, contravened the General Agreement on Tariffs and Trade (GATT). ${ }^{11}$ The case was settled before it could reach the Panel

an example of a Recommendation adopted in terms of the Plan, see NEAFC Recommendation 3: 2017 (2017), http://www.neafc.org/system/files/Rec.3\%20-\%20Herring.pdf (accessed 15 February 2017).

3 Council Regulation 1005/2008, OJ 2008 L 286/1.

4 Council Regulation 1026/2012, OJ 2012 L 316/34.

5 United Nations Convention on the Law of the Sea 1982, 1833 UNTS 396, arts. 63-64.

6 Transshipment refers to the unloading of fish from one vessel to another in port for the purpose of onward carriage to another port.

7 Council Regulation 793/2013, OJ 2013 L 223/1.

8 Faroes-Herring, supra note 1.

9 WTO, Understanding on Rules and Procedures Governing the Settlement of Disputes, 1994.

10 Implementing Council Regulation, supra note 7.

11 WTO, General Agreement on Tariffs and Trade, 1994. 
stage of proceedings. The Faroes agreed to accept a lower quota for herring 40,000 tonnes as opposed to the 105230 tonnes. This quota was slightly higher than that allocated to it by the other NEAFC parties - 31,000 tonnes. In August 2014, the EU withdrew the Implementing Regulation. However, the settlement of the case leaves unresolved an important issue regarding the relationship between port state measures, such as the EU Regulations, ${ }^{12}$ and WTO law. This paper endeavours to resolve this issue as it pertains to Faroes-Herring, considering whether the EU Regulations, and EU practice in enforcing these regulations, can be reconciled with WTO law. As similar trade issues arise with the designation of NSF countries, under the Shared Stocks Regulation, and non-cooperating countries, ${ }^{13}$ under the EU's IUU Regulation, the provisions for designating both NSF and non-cooperating countries are useful for analysis of the EU Regulations, and both will be mentioned throughout the paper.

By way of background, this paper, in Section 2, highlights several issues of importance to the analysis before considering how Panels and the Appellate Body might resolve a conflict between WTO law and the EU Regulations in Sections 3 and 4.

Section 3 considers whether conflict provisions, specifically the use of inter se agreements, ${ }^{14}$ could be used to resolve a conflict over port state measures that may arise at the WTO. The Agreement on Port State Measures to Prevent, Deter, and Eliminate Illegal, Unreported, and Unregulated Fishing (PSMA), ${ }^{15}$ for example, could be considered an inter se agreement concluded by specific WTO members. A number of commentators believe that inter se agreements modifying WTO law are possible. ${ }^{16}$ However, findings in the recent case of PeruAgricultural Products ${ }^{17}$ suggest that the Appellate Body does not agree. WTO jurisprudence also suggests a preference for resolving disputes through reconciliation of laws, rather than conflict maxims.

Section 4 then examines whether the EU Regulations are compliant with WTO law. The analysis focuses on compliance with GATT Article XX, specifically the

12 For purposes of this paper, 'EU Regulations' refer to the IUU, Shared Stocks, and Implementing Regulations.

13 Non-cooperating countries are designated under Chapter VI of the EU's IUU Regulation, supra note 3. Non-cooperating countries are those which have not effectively policed IUU fishing in their own waters.

14 Agreements made between some of the parties to an agreement modifying that agreement only between those parties.

15 Agreement on Port State Measures to Prevent, Deter, and Eliminate Illegal, Unreported, and Unregulated Fishing 2009, United Nations Treaty Collection No. 54133.

16 International Law Commission, Fragmentation of International Law: Difficulties Arising from the Diversification and Expansion of International Law, UN Doc. A/CN.4/L.682, 13 April 2006, paras. 306-318; E. Vranes, Trade and the Environment: Fundamental Issues in International Law, WTO Law and Legal Theory (Oxford University Press, 2009), at 82 and 91; Joost Pauwelyn, Conflicts of Norms in Public International Law: How WTO Law Relates to other Rules of International Law (Cambridge University Press, 2003), at 52-54.

17 WTO, Peru - Additional Duty on Imports of Certain Agricultural Products, 20 July 2015, WT/ DS457/AB/R. 
Chapeau, which is generally the downfall of unilateral environmental regulations. A number of ways in which the EU Regulations may contravene the Chapeau are explored, including the EU's contribution to, and struggle with, IUU fishing in its own waters, the breakdown of multilateral talks in NEAFC, and potential disguised motives of the EU in promulgating specific implementing regulations. In addressing these issues, the paper points to ways in which a Panel or Appellate Body can reconcile international trade and fisheries law by taking account, in its analysis, of international fisheries law and international practice in combatting IUU fishing. This section argues that such an approach is in keeping with WTO jurisprudence and practice. It is also consonant with the apparent desire of Panels and the Appellate Body to reconcile WTO law and international law, particularly international environmental law. US-Shrimp ${ }^{18}$ is a good example of this, with its 'evolutionary' interpretation of Article $\mathrm{XX}(\mathrm{g})$ to give effect to concerns about living resources being subject to depletion. ${ }^{19}$ In the case of the EU Regulations and port state measures, however, Section 4 suggests that a Panel or Appellate Body need not even adopt this type of evolutionary interpretation, as WTO jurisprudence already has mechanisms that would allow international fisheries law and practice to be taken into account in resolving a case.

\section{Background}

\subsection{The Faroe Islands}

The Faroe Islands is a small self-governing fishing nation situated in the North Atlantic Ocean. It is under the sovereignty of Denmark but is not part of the EU. Its economy is almost entirely dependent on its fishing and agriculture industries, and it generally has a strong fishing conservation record. ${ }^{20}$

In $2014,95 \%$ of Faroese goods exports (excluding ships and aircraft) were fishery products, ${ }^{21} 35 \%$ of the Faroese fish catch was made up of herring and mackerel, ${ }^{22}$ and nearly $50 \%$ of total Faroese exports went to the EU. ${ }^{23}$ Trade with the EU in herring and mackerel is, therefore, extremely important to the Faroes, and, because of the Faroese economy's dependence on fish exports, the trade ban was particularly harmful to it. However, the conduct of the Faroes was also particularly

18 WTO, US - Import Prohibition of Certain Shrimp and Shrimp Products, 12 October 1998, WT/DS58/AB/R.

19 Ibid., para. 130.

20 Faroe Islands, Sustainable Fisheries (video) (2016), http://www.faroeislands.fo/economy-business/ fisheries/ (accessed 2 February 2017).

21 M. H. Rasmussen, Current Trends in the Faroese Economy (2014), http://www.nationalbanken.dk/ en/publications/Documents/2014/09/Current\%20Trends\%20in\%20the\%20Faroese\%20Economy_Mon32014.pdf (accessed 24 February 2017).

22 Hagstova Føroya, Faroe Islands in Figures 2016 (2016), http://www.hagstova.fo/sites/default/files/ Faroe_Islands_in_figures_2016.pdf (accessed 24 February 2017) at 28.

23 Ibid., at 34 . 
harmful to the environment. By setting such a high unilateral quota for herring, the Faroes may have caused the collapse of the herring stock. Moreover, its conduct appears to fall within the wide definition of IUU fishing in Section 3 of the Food and Agriculture Organization's (FAO) International Plan of Action to prevent, deter and eliminate illegal, unreported, and unregulated fishing (IPOA-IUU), ${ }^{24}$ which is repeated almost verbatim in the EU's IUU Regulation ${ }^{25}$ (as in many instruments dealing with IUU fishing $)^{26}$. The Shared Stocks Regulation covers aspects of this definition relevant to Faroes-Herring, specifically whether a country does not cooperate in the management of a stock of common interest and either fails to adopt fisheries management measures or does so in a manner which, when taken together with the measures of other countries, renders the stock unsustainable. ${ }^{27}$

\subsection{IUU fishing and the EU regulations}

IUU fishing has been estimated to account for between $13 \%$ and $31 \%$ of catches, amounting in 2003 to a loss of between 5 and 11 billion US dollars worldwide. ${ }^{28}$ It has also been linked to drug, arms, and human trafficking, as well as forced labour. ${ }^{29}$ There have been several important developments in this area in the last 20 years, as states and international bodies, particularly the FAO, attempt to deal with the problem. Over a number of years, the FAO has facilitated the negotiation and promulgation of several instruments aimed at preventing IUU fishing, including the IPOA-IUU ${ }^{30}$ and the PSMA. ${ }^{31}$ The FAO has also made it clear that port state measures can include trade measures. ${ }^{32}$

Trade and trade-related measures, such as import bans and transshipment bans, are seen as important in combatting IUU fishing. Provided they are properly enforced, these measures are an effective way to prevent IUU fish getting into a

24 FAO, International Plan of Action to Prevent, Deter, and Eliminate Illegal, Unreported, and Unregulated Fishing (2001), http://www.fao.org/docrep/003/y1224E/Y1224E00.HTM (accessed 24 February 2017).

25 See the definition of IUU fishing in the IUU Regulation, supra note 3, art. 2.2.

26 See, for example, PSMA, supra note 15, art. 1(e); Illegal, Unreported, and Unregulated Fishing Enforcement Act (Law of 11 May 2015) [2015] H.R. 774, Public Law No: 114-81, s 303(2); NEAFC, NEAFC Scheme of Control and Enforcement (2010: latest update on 9 February 2017), https://www. neafc.org/book/export/html/15254 (accessed 24 February 2016), art. 1(L).

27 Shared Stocks Regulation, supra note 4, art. 3.

28 D. Agnew et al., 'Estimating the Worldwide Extent of Illegal Fishing', PLOS 1 (2009).

29 Directorate-General for Internal Policies, Illegal, Unreported, and Unregulated Fishing: Sanctions in the EU (2014), http://www.europarl.europa.eu/RegData/etudes/STUD/2014/529069/IPOL_STU(2014) 529069_EN.pdf (accessed 15 February 2017) at 22-23.

30 IPOA-IUU, supra note 24.

31 PSMA, supra note 15.

32 The FAO has said that port state measures 'typically include requirements related to prior notification of port entry, use of designated ports, restrictions on port entry and landing/transshipment of fish, restrictions on supplies and services, documentation requirements and port inspections, as well as related measures, such as IUU vessel listing, trade-related measures and sanctions', FAO, Port State Measures (2017), http://www.fao.org/fishery/psm/en (accessed 24 February 2017). 
country, either to be sold in that country, or to be transported through that country for sale elsewhere. This has led many states, ${ }^{33}$ including the US, ${ }^{34}$ as well as the EU, to promulgate domestic legislation, including port state measures, to prevent IUU fish entering their markets. These are important instruments in light of the failure of flags of convenience states, ${ }^{35}$ such as Liberia and Panama, to effectively police IUU fishing by vessels on their registries. ${ }^{36}$

The Shared Stocks Regulation allows the EU to declare a country an NSF country, and impose quantitative restrictions on imports of fish caught under its 'control'. These restrictions extend to imports of fishery products made of or containing such fish, including fishery products made by other countries. ${ }^{37}$ In FaroesHerring, the Implementing Regulation provided that herring and mackerel caught under the 'control' of the Faroes was that caught by vessels flying the Faroese flag or those vessels flying the flag of other states that were authorized to fish in the Faroes exclusive economic zone (EEZ), or chartered by a Faroese firm or authorities. ${ }^{38}$ The Shared Stocks Regulation also has a number of other, less trade restrictive, measures that can be imposed on an NSF country. ${ }^{39}$

The IUU Regulation allows for a trade ban to be imposed on a non-cooperating country. The EU gives a warning (yellow card) at which time the country must put in place procedures to deal with the problem if it wants to avoid a ban. Countries that have received these cards in the past include Thailand, Korea, Ghana, and the Philippines. ${ }^{40}$ The IUU Regulation also allows for sanctions to be imposed on nationals for IUU fishing, including seizure of catches and fishing gear, banning access to EU ports apart from the vessel's homeport, suspension or withdrawal of fishing rights, and, in serious cases, administrative and criminal sanctions. ${ }^{41}$

In creating and enforcing these regulations, the EU has done much to prevent IUU fishing in the waters of third party states, and to fulfil the EU's obligations under treaties to which it is a party, including ${ }^{42}$ UNFSA $^{43}$ and the PSMA.

33 See FAO, International Plan of Action to Prevent, Deter, and Eliminate Illegal, Unreported, and Unregulated Fishing (2017), http://www.fao.org/fishery/ipoa-iuu/npoa/en (accessed 15 February 2017), for plans of action created by 17 states to prevent IUU fishing, including Australia, Canada, Japan, and Chile.

34 US IUU Act, supra note 26.

35 A flag of convenience state allows vessels owned by nationals of other states on to its shipping register. Lax enforcement, particularly with regard to safety and labour requirements, often characterize these flags, and they are often used for criminal activity.

36 Agnew, supra note 28.

37 Shared Stocks Regulation, supra note 4, arts 4(1)(a)-(d).

38 Implementing Council Regulation, supra note 7, art. 3(d).

39 Shared Stocks Regulation, supra note 4, art. 4.

40 European Commission, Questions and Answers on the EU's Fight against Illegal, Unreported, and Unregulated (IUU) fishing (2015), http://europa.eu/rapid/press-release_MEMO-15-4807_en.htm (accessed 24 February 2017).

41 IUU Regulation, supra note 3, arts 37 and 43-45.

42 UNCLOS, supra note 5.

43 United Nations Convention on the Law of the Sea of 10 December 1982 relating to the Conservation and Management of Straddling Fish Stocks and Highly Migratory Fish Stocks 1995, 2167 UNTS 109. 
However, these treaties, like the EU Regulations, have provisions that may conflict with WTO obligations.

\subsection{The relationship between trade and fisheries law}

The FAO has tried to prevent conflict between trade and fisheries law by including reconciliation clauses in some of its instruments. The FAO Fisheries Code ${ }^{44}$ provides that international fisheries trade should be in accordance with the principles, rights, and obligations of the WTO. ${ }^{45}$ The IPOA-IUU similarly provides that states must prohibit trade in fish caught using IUU fishing methods, and must do so in accordance with the principles, rights, and obligations of the WTO. ${ }^{46}$

Despite these efforts at reconciliation, however, the relationship between trade and fisheries law has often been a fraught one. This can be seen in a number of WTO cases. ${ }^{47}$ As mentioned, Faroes-Herring was not the first time domestic port state measures were an issue at the WTO, although Chile-Swordfish, ${ }^{48}$ too, was settled before reaching a Panel. It is also true that not all international fisheries' instruments have reconciliatory clauses, such as those found in the FAO Fisheries Code and IPOA-IUU. The PSMA makes no mention of complying with WTO rules and neither does UNFSA, and both contain provisions which may contravene WTO law. The PSMA obliges contracting parties to deny entry to ports to those vessels engaged in IUU fishing, ${ }^{49}$ while Article 23(3) of UNFSA provides that states may prohibit landings and transshipments where fish have been taken in a manner which 'undermines the effectiveness of subregional, regional or global conservation and management measures on the high seas'. ${ }^{50}$ Although article 23(3) only applies to fish taken on the high seas, Article 23(1) of UNFSA provides that a port state has 'the right and the duty to take measures in accordance with international law, to promote the effectiveness of subregional, regional and global conservation and management measures'. This would include catches taken in a country's EEZ. Specifically in the case of Faroes-Herring, Article 23(4) of the NEAFC Scheme ${ }^{51}$ obliges a NEAFC party to prevent another NEAFC party's vessel from landing, transshipping a catch, or using its ports when the vessel

44 FAO, FAO Code of Conduct for Responsible Fisheries (1995), http://www.fao.org/docrep/005/ v9878e/v9878e00.htm (accessed 24 February 2017).

45 Ibid., art. 6.14.

46 IPOA-IUU, supra note 24, s 65.

47 WTO, US - Prohibition of Imports of Tuna and Tuna Products from Canada, 22 December 1981, L/5198-29S/91; WTO, Canada-Measures Affecting Exports of Unprocessed Herring and Salmon, 20 November 1987, L/6268-35S/98; WTO, Chile-Measures Affecting the Transit and Importation of Swordfish: Request for Consultations by the European Communities, 26 April 2000, WT/DS193/1 G/L/367.

48 Ibid., Chile-Swordfish.

49 PSMA, supra note 15, arts 9(4) and 11.

50 UNFSA, supra note 43.

51 NEAFC Scheme, supra note 26. 
is in breach of local regulations dealing with fisheries resources in the Convention Area (such as the EU Regulations). These provisions appear to violate at least Article V of the GATT, which provides for freedom of transit for WTO members through the territory of other members with no discrimination based on criteria such as the flag of vessels and the place of origin of the vessel or goods. ${ }^{52}$

However, with the notable exception of EC-Biotech, ${ }^{53}$ which has been largely ignored in subsequent WTO jurisprudence, the WTO has, in recent years, taken greater cognisance of environmental and integration concerns. This can be seen in its Doha Round negotiations on fisheries subsidies and the relationship between multilateral environmental agreements and WTO law, and in WTO jurisprudence, which has found the prevention of air pollution, waste caused by retreaded tyres and dolphin and turtle mortality to be important issues under Article XX, and, in US-Shrimp, the Appellate Body took cognisance of UNCLOS and the Convention on International Trade in Endangered Species (CITES) in making its findings. ${ }^{54}$ Certainly, the trade-centric approach in the GATT-era Tuna cases ${ }^{55}$ seems to have vanished in light of this finding. A concern for fisheries was also expressed by several WTO members in negotiating the Trans-Pacific Partnership (TPP), which contains fisheries provisions requiring the elimination of harmful fishing subsidies, implementation of a fisheries management system designed to prevent overfishing and overcapacity, and cooperation to prevent IUU fishing. 56

With these considerations in mind, this paper now turns to consider how Panels and the Appellate Body deal with conflict in the WTO, and how the recent practice and jurisprudence of the WTO may influence their approach in deciding a case such as Faroes-Herring, or a case involving a non-cooperating country.

\section{Resolving conflict in the WTO}

\subsection{Inter Se Agreements}

International fisheries law is comprised of a large number of overlapping treaties and international bodies whose memberships do not correspond exactly, and many fisheries agreements are soft law instruments, such as the FAO Fisheries Code and IPOA-IUU. There are also no norms that could be considered

52 GATT, supra note 11.

53 WTO, EC-Measures Affecting the Approval and Marketing of Biotech Products, 29 September 2006, WT/DS291/R; WT/DS292/R; WT/DS293/R.

54 US-Shrimp, supra note 18, paras. 130-132.

55 WTO, US - Restrictions on Imports of Tuna, 3 September 1991, DS21/R, unadopted; WTO, US-Restrictions on Imports of Tuna, 6 June 1994, DS29/R, unadopted.

56 Trans-Pacific Partnership Agreement, 2015, http://tpp.mfat.govt.nz/text (accessed 25 February 2017), art. 20.16. 
hierarchically superior in these regimes and conflict maxims such as the lex specialis ${ }^{57}$ and lex posterior, ${ }^{58}$ as advocated by the International Law Commission (ILC) in its study on fragmentation in international law, ${ }^{59}$ are usually not helpful in resolving conflict. ${ }^{60}$ Thus, traditional methods of resolving legal conflict generally do not assist in the resolution of a conflict between international trade and fisheries law.

In the specific case of port state measures, however, the promulgation of a recent, binding treaty - the PSMA - may mean that conflicts could potentially be resolved using traditional conflict principles. Thus, while the lex superior ${ }^{61}$ and lex specialis still face difficulties - namely that there are no hierarchically superior norms in fisheries law, and, when dealing with two distinct bodies of law, it is difficult to determine which agreement is the more specialized - the lex posterior may have some application in resolving trade and fisheries conflicts. Problems with the lex posterior generally arise because it is not clear which treaty is entered into later in time when one party joins the first treaty first, while another party joins the second treaty first. In the case of the WTO and PSMA, however, the PSMA is likely to be later in time in all cases, given that it was adopted in 2009, and entered into force only in June 2016, when the WTO already had over 160 members.

One specific subset of the lex posterior-inter se agreements - is particularly apposite to conflict resolution, given that these agreements allow some of the parties to modify an agreement amongst themselves, so that one agreement need not necessarily trump another for all parties to that agreement. As mentioned, a number of commentators believe that WTO law allows for the use of inter se agreements and that these should be used in the WTO. ${ }^{62}$ Article 41 of the Vienna Convention on the Law of Treaties (VCLT) also allows for inter se agreements to modify treaties, provided third parties are not affected and the parties to the inter se agreement notify the parties to the original agreement. The ILC believes that this need not be overt notification, provided the intention to modify is 'universally apparent' from the modifying agreement. ${ }^{63}$ The PSMA could, therefore, potentially be used as an inter se agreement modifying the GATT, if it could be shown that this was the intention of the parties.

The PSMA does not have a provision stating that there should not be conflict with WTO law, like the FAO Fisheries Code and IPOA-IUU. This suggests that modification of provisions conflicting with the PSMA may have been the intention

57 The special law prevails over the general law.

58 The later law prevails over the earlier law.

59 ILC Study, supra note 16.

60 M. A. Young, Trading Fish, Saving Fish (Cambridge University Press, 2011), at 87-88.

61 Hierarchically superior laws such as jus cogens norms trump other norms.

62 See note 16 above.

63 ILC Study, supra note 16, paras. 306-318. 
of the parties, given the potential for port state measures to conflict with WTO law. Of course, this method of resolving conflict has limited application in a WTO dispute on port state measures, given that the parties to the case must also be parties to the agreement designated as an inter se agreement, and the PSMA has only 46 ratifications as of 7 May 2017. It should be noted, however, that the EU is a member, as are certain countries against which it has issued warnings under the IUU Regulation, such as Thailand and South Korea. As such, use of inter se agreements may be a way to resolve conflict in WTO cases involving the EU Regulations. However, the recent case of Peru-Agricultural Products ${ }^{64}$ appears to have removed this possibility. Thus far, when true conflict has arisen in the WTO, this has primarily been between WTO Agreements and preferential trade agreements (PTAs). In PTA cases, the Appellate Body and Panels have preferred WTO law over the PTA in question, refusing to accept that a PTA could trump or modify WTO law. ${ }^{65}$ Although cases involving PTAs could be said to be distinguishable from trade and environment cases, as the WTO often struggles with its role in the former, its reasoning is not always confined to PTAs. In PeruAgricultural Products, ${ }^{66}$ the Appellate Body found that Article 41 of the VCLT could not be invoked by Peru to justify a WTO-inconsistent PTA, because the WTO agreements contain specific provisions dealing with amendments, waivers, and exceptions 'which prevail over the general provisions of the Vienna Convention, such as Article 41'.67 In mentioning amendments and waivers, and not simply exceptions, which PTAs form to the multilateral trading system, the prohibition on inter se agreements does not appear to be limited to PTAs. This is unfortunate, as the process of amending agreements within the WTO is cumbersome, requiring consent by all WTO members, many of whom would not be affected by the matter. Of course, Peru-Agricultural Products may be confined to the case of PTAs in future. However, it has left open the unfortunate possibility that use of inter se agreements, as a conflict resolution mechanism, is not available to WTO members in cases involving port state measures. If this is the case, it is necessary to find a different method to deal with such conflicts.

\subsection{Reconciling laws}

To deal specifically with conflict between international fisheries and trade law, Young has developed an alternative method of conflict resolution. This applies to both law making and application, including at the level of dispute settlement. Her method involves taking cognisance of relevant non-WTO international law

64 Peru-Agricultural Products, supra note 17.

65 Ibid., also see WTO, Mexico - Tax Measures on Soft Drinks and Other Beverages, 6 March 2006, WT/DS308/AB/R.

66 Ibid., Peru-Agricultural Products, supra note 17.

67 Peru-Agricultural Products, supra note 17, paras. 5.97 and 5.112. 
in deciding a case, in order to avoid fragmentation between non-WTO law and WTO law. Non-WTO law can be brought to the attention of a Panel or the Appellate Body through consultation with secretariats of other IGOs and acceptance of amicus briefs from NGOs and other bodies. To assist both these bodies and other actors in the WTO to better understand when non-WTO law is relevant to a dispute, Young advocates greater collaboration between the WTO secretariat and other secretariats, and transparency regarding the use by the WTO of amicus briefs. ${ }^{68}$ Young is of the view that the Appellate Body applied this method of reconciliation in US-Shrimp as it took into account non-WTO sources in deciding the dispute, stated clearly that Panels could accept amicus briefs, and, in applying nonWTO law, did not consider it relevant that not all the parties to the dispute were parties to the non-WTO agreements. In her view, the Panel in US-Shrimp 21.569 took this even further and stated explicitly that the parties were bound by the international law rules cited in US-Shrimp. ${ }^{70}$

EC-Civil Aircraft ${ }^{71}$ provides support for Young's proposition that the WTO considers other sources of international law when interpreting WTO agreements, thereby harmonizing these with international law. In this case, the Appellate Body held that 'a delicate balance must be struck between, on the one hand, taking due account of an individual WTO member's international obligations and, on the other hand, ensuring a consistent and harmonious approach to the interpretation of WTO law among all WTO members.' 72

A number of other commentators take similar views. According to Flett, a WTO litigator, Panels and the Appellate Body do use non-WTO agreements as context for their decisions, without explicitly mentioning these in their judgments, ${ }^{73}$ and Peters believes that law-applying bodies, including the WTO, first attempt to avoid conflict 'by harmonizing the various international rules rooted in different regimes'. ${ }^{74}$ These are all indications that, from a practical perspective, non-WTO agreements are generally used to resolve conflict even when parties in the case are not parties to those agreements, as least where PTAs are not involved. Indeed, Panels and the Appellate Body rarely raise conflict principles when deciding cases and there appears to be something of an antipathy towards resolution of

68 Young, supra note 60, 224-239.

69 WTO, US - Import Prohibition of Certain Shrimp and Shrimp Products-Recourse to Article 21.5 of the DSU by Malaysia, 22 October 2001, WT/DS58/AB/RW.

70 Young, supra note 60, at 202.

71 WTO, EC and Certain Member States - Measures Affecting Trade in Large Civil Aircraft, 18 May 2011, WT/DS316/AB/R.

72 Ibid., paras. $844-845$.

73 James Flett, 'Importing Other International Regimes into World Trade Organization Litigation', in M. A. Young (ed.), Regime Interaction in International Law: Facing Fragmentation (Cambridge University Press, 2012) 260, at 303.

74 A. Peters, 'Fragmentation and Constitutionalism', in A. Orford, F. Hoffmann, and M. Clark (eds.), The Oxford Handbook of the Theory of International Law (Oxford University Press, 2016) 1011, at 1024-1025. 
conflict in this manner. The Panel in EC-Poultry, for example, stated that past panels had been cautious in applying the lex posterior presumption in interpreting Member's tariff schedules and that this presumption could not override the intention of the parties. ${ }^{75}$ Thus, reconciling WTO law with non-WTO law through interpretation, regardless of whether there is a potential conflict between these laws, probably best reflects the approach of the WTO to resolving conflicts.

The question then is whether reconciliation of international trade and fisheries law would be possible in a dispute on port state measures - in this case the EU Regulations. Section 4 attempts to answer this question. If reconciliation is not possible, it is difficult to see how a Panel or Appellate Body would resolve the conflict. It is to be hoped that a trade-centric stance would not be taken, at the expense of integration, as occurred in Peru-Agricultural Products, and that the use of inter se agreements remains a possibility to resolve such conflicts.

\section{Reconciliation in Faroes-Herring}

As discussed in Section 2, recent WTO jurisprudence and practice is tending towards greater incorporation of international environmental law and non-WTO law, particularly international fisheries law. Indeed, Urakami has suggested that after US-Shrimp the Appellate Body 'passed the point of no return' with regard to weighing environmental values against free trade concerns. ${ }^{76}$ Thus, if international trade and fisheries law is to be reconciled in Faroes-Herring or a case involving a non-cooperating country, it is necessary to both analyse the EU Regulations for WTO-compliance and to consider ways in which Panels and the Appellate Body can take account of international fisheries law, including international practice to combat IUU fishing, in determining WTO-compliance. By doing so, a Panel or Appellate Body can avoid a conflict between international trade and fisheries law. This section sets out a number of suggestions in this regard. The majority of these suggestions are supported by WTO jurisprudence and practice.

\subsection{The GATT and TBT}

Young has suggested that the IUU Regulation may be subject to the Agreement on Technical Barriers to Trade (TBT), because of its emphasis on traceability of fish products and its creation of a catch certification scheme, ${ }^{77}$ although she does not

75 WTO, EC-Measures Affecting the Importation of Certain Poultry Products, 23 July 1998, WT/ DS69/R, para. 206.

76 K. Urakami, 'Unsolved Problems and Implications for the Chapeau of GATT Article XX after the Reformulated Gasoline Case', in E. Weiss, J. H. Jackson, and N. Bernasconi-Osterwalder (eds.), Reconciling Trade and Environment (Martinus Nijhoff Publishers, 2008) 171, at 185.

77 Catch certification, or documentation, schemes trace fish or fishery products from the point of capture and throughout the supply chain through generation of documents setting out certain prescribed information which verifies that the fish or fishery products were not caught using IUU methods. 
come to a definite conclusion on this theory, given contradictory jurisprudence on the TBT. ${ }^{78}$ This does not affect the case of Faroes-Herring, however, which challenged only the Shared Stocks and Implementing Regulations under Articles I, V, and XI of the GATT. ${ }^{79}$ In addition, while the articles on non-cooperating countries do rely on those aspects of the IUU Regulation that Young believes may make it a technical regulation, these articles do not directly lay down product characteristics or processes and production methods, as required by TBT Annex 1.1. Thus, because this paper deals only with non-cooperating countries for comparative purposes, and a full analysis of the IUU Regulation is beyond the scope of the paper, this section undertakes an inquiry only into the GATT-compliance of the EU Regulations as they pertain to Faroes-Herring and non-cooperating countries.

In doing so, this section focuses primarily on the Article XX Chapeau, as it is most likely to be in contention in a case involving the EU Regulations. This is because, firstly, it is likely that the EU Regulations violate at least one of the three substantive GATT provisions cited by the Faroes, ${ }^{80}$ which would lead to Article XX - the exceptions provision - being invoked by the EU. Secondly, there has been a great deal of guidance on Articles XX $(\mathrm{a})-(\mathrm{j})$ in WTO jurisprudence, particularly Articles XX(b) (measures necessary to protect human, animal, or plant life or health), ${ }^{81}$ and XX(g) (measures related to the conservation of exhaustible natural resources), 82 and the requirements of these articles are narrower than those of the Chapeau, which covers the broad concepts of unjustifiable and arbitrary discrimination and disguised restrictions on international trade. This means that WTO members may find compliance with Articles $\mathrm{XX}(\mathrm{a})-(\mathrm{j})$ relatively straightforward, and yet struggle to comply with the requirements of the Chapeau, which must also be satisfied under Article XX for a measure to be GATT-consistent.

The EU Regulations have clearly taken past jurisprudence on Articles XX(a)-(j) into account, and seem to comply with at least Article $\mathrm{XX}(\mathrm{g})$, and possibly also Article XX(b). ${ }^{83}$ Indeed, Young has labelled the IUU Regulation a model of WTO-compliance. ${ }^{84}$

78 M.A. Young, Trade Related Measures to Address Illegal, Unreported, and Unregulated Fishing, June 2015, http://e15initiative.org/wp-content/uploads/2015/09/E15-Oceans-and-Fisheries-Young-FINAL. pdf (accessed 7 May 2017) at 11-12.

79 Faroes-Herring, supra note 1.

80 For a comprehensive overview, see K. Auld, 'Can Port State Measures taken against RMFO Partners be reconciled with International Trade Law? A Critical Analysis of the EU Shared Stocks Regulation in light of the Herring Dispute', LLM thesis, https:/open.uct.ac.za/bitstream/item/23543/thesis_law_2016_auld_kathleen.pdf? sequence $=1$, at 16-24.

81 See WTO, European Communities-Measures Affecting Asbestos and Asbestos-Containing Products, 12 March 2001, WT/DS135/AB/R; WTO, Brazil-Measures Affecting Imports of Retreaded Tyres, 3 December 2007, WT/DS332/AB/R, amongst others.

82 See US-Shrimp, supra note 18; WTO, US-Standards for Reformulated and Conventional Gasoline, 29 April 1996, WT/DS2/AB/R, amongst others.

83 For a full discussion of the reasons for this, see Auld, supra note 80, at 27-36.

84 Young, supra note 78 , at 16. 
The EU has also attempted to comply with the Chapeau as it has been analysed in WTO jurisprudence. The EU Regulations are flexible within the meaning of the term in US-Shrimp, where the Appellate Body found that the turtle regulations discriminated unjustifiably because they did not take into account that different situations prevail in different countries. ${ }^{85}$ The IUU Regulation sets out a number of criteria that should be considered when designating a non-cooperating country, including capacity of developing countries, ${ }^{86}$ and provides for a warning to be given to countries before a trade ban is imposed. ${ }^{87}$ The Shared Stocks Regulation provides that, when imposing sanctions, 'the Commission shall ... evaluate the environmental, trade, economic, and social effects of those measures in the short and long terms and the administrative burden associated with their implementation' ${ }^{88}$ The EU Regulations also contain many due process-type provisions, which appear to be an element of the arbitrary discrimination analysis after US-Shrimp. ${ }^{89}$ These include a right to be heard before trade measures are taken, and the provision of written, reasoned decisions for imposing measures through the promulgation of implementing regulations, which are then made public. ${ }^{90}$ Finally, in creating the EU Regulations, the EU engaged with affected trading partners, ${ }^{91}$ presumably to satisfy any requirement of multilateral cooperation that may arise from WTO jurisprudence. ${ }^{92}$

However, past jurisprudence on the Chapeau indicates that even if a measure complies with all of the requirements in one of the provisional articles, it invariably falls down on the Chapeau. Jurisprudence on the Chapeau is convoluted at best, the Chapeau requirements are broad, and there are many factors that can indicate discrimination, which are case-specific and can sometimes be beyond the control of the WTO member that created the measure. This makes it difficult for a WTO member to ensure that its measures are consistent with the Chapeau, even if it attempts to meet requirements laid out in WTO jurisprudence. There has also been little to no guidance on the second element of the Chapeau - whether or not a measure is a disguised restriction on international trade. This means that those factors indicating Chapeau-inconsistency in the case law do not cover the field.

The next section considers how factors indicating unjustifiable and arbitrary discrimination are determined in WTO jurisprudence, and suggests two potentially

85 US-Shrimp, supra note 18, paras. 161-165.

86 IUU Regulation, supra note 3, art. 31(5)(d).

87 Ibid., art. 32 .

88 Shared Stocks Regulation, supra note 4, art. 5(4).

89 See, e.g., Urakami, supra note 76, at 182, L. Briggs, “Exhaustible Natural Resources”: The Role of Precedent in the GATT Article XX(g) Exception', in E. Weiss, J. H. Jackson, and N. BernasconiOsterwalder (eds.), Reconciling Trade and Environment (Martinus Nijhoff Publishers, 2008), 265, at 296; contra L. Bartels, 'The Chapeau of the General Exceptions in the WTO GATT and GATS Agreement: A Reconstruction', 109 American Journal of International Law (2015) 95, at 122.

90 Ibid., art. 6; Implementing Council Regulation, supra note 7, Preamble; IUU Regulation, supra note 3 , art. 32 .

91 Young, supra note 78, at 10.

92 See section 4.2 .2 below. 
discriminatory factors in Faroes-Herring and the case of non-cooperating countries. Thereafter, the concept of a disguised restriction, and the form this could take in such cases, is examined.

\subsection{Discrimination}

Drawing on WTO jurisprudence, Bartels has suggested that Panels and the Appellate Body, in requiring that measures meet criteria such as multilateral cooperation and flexibility, in fact apply a type of necessity test-considering whether there is a less discriminatory alternative to the measure at issue which achieves a legitimate objective. ${ }^{93}$ Shenk also argues that the Appellate Body in US-Gasoline applied a necessity test under the Chapeau. However, he criticizes the apparently wide discretion this gives Panels and the Appellate Body, and recommends that they apply this approach 'in a principled manner, taking into account the importance of the environmental interests at issue and the seriousness of the alleged violation of international trade rules'. ${ }^{94}$ Shenk was writing at the time of US-Gasoline and the subsequent US-Shrimp case seems to support this suggestion, finding that those aspects of the measure that constitute unjustifiable discrimination should be considered cumulatively. ${ }^{95}$ This implies that a measure with one, rather than multiple, discriminatory aspects, may not be GATT-inconsistent. Using a necessity test to determine discrimination is, thus, supported by both commentators and WTO jurisprudence.

Bartels has a number of theories as to what constitutes a legitimate objective for a measure. ${ }^{96}$ Objectives that could be legitimate in Faroes-Herring or a case involving a non-cooperating country include compliance with one of the provisional articles such as Article $\mathrm{XX}(\mathrm{g}),{ }^{97}$ compliance with international agreements and standards, such as multilateral fisheries instruments and rules of RFMOs, ${ }^{98}$ and fulfilling an objective of importance to WTO Members, as suggested by WTO jurisprudence and practice. ${ }^{99}$

With this in mind, this paper will now deal with two, apparently less discriminatory, alternatives to the EU Regulations that could lead to a violation of the discrimination element of the Chapeau.

93 Bartels, supra note 89 , at 118-121.

94 M. D. Shenk, 'United States - Standards for Reformulated and Conventional Gasoline', 90 The American Journal of International Law (1996) 669, at 672-673.

95 US-Shrimp, supra note 18, para. 176.

96 Bartels, supra note 89 , at 118

97 Ibid.

98 Ibid. Bartels notes that discrimination can be justified for reasons recognized in international standards. In illustrating this point, he refers to EC-Tariff Preferences, which states that these standards can be set out in, inter alia, multilateral instruments.

99 Ibid. Bartels suggests that discrimination could be justified by reference to other WTO agreements and that the Appellate Body may also recognize legitimate objectives 'without reference to other normative considerations', although the latter is less likely than the other legitimate objectives discussed. 


\subsubsection{IUU Fishing in the EU}

(a) EU conduct leading to IUU fishing. Undeniably, certain EU fishers engage in IUU fishing. This is the case in every state in the world and is not, by itself, grounds for a finding of unjustifiable or arbitrary discrimination. However, the EU has played a large part in the rise of IUU fishing in its waters through, firstly, the provision of harmful capacity-enhancing subsidies to its fishers, and, secondly, allowing quotas to be set above levels necessary to maintain sustainable fish stocks.

The EU has subsidized its fishers for many years, including, among others, subsidies for new vessels and vessel modernization, fuel subsidies, and fisheries partnership subsidies. ${ }^{100}$ This type of capacity-enhancing subsidization creates potential for overfishing and flouting of quotas, ${ }^{101}$ the very problems that the EU is attempting to prevent with the EU Regulations. Spanish fishers are some of the worst offenders when it comes to IUU fishing, although there are others, ${ }^{102}$ yet the EU and Spain have, in the past, subsidized not only the Spanish fishing industry but specific offenders. ${ }^{103}$ Due primarily to capacity building through subsidies, the Spanish fleet is very large, ${ }^{104}$ and in 2012 it was estimated that a third of the fish caught by Spanish fleets was subsidized. ${ }^{105}$ Apart from increasing IUU fishing, continuing to give subsidies to those vessels engaged in IUU fishing incentivizes those engaged in IUU fishing. This is at odds with the EU's conduct towards third party countries engaged in, or allowing, IUU fishing, such as the Faroes and the non-cooperating countries.

Another problem is that the EU sometimes allows EU members to set quotas higher than scientific evidence advises, which has led to stocks being in unsustainable states. ${ }^{106}$ In 2015, EU Ministers allowed the UK to set quotas above that recommended to maintain the maximum sustainable yield of certain fish

100 A. Schroeer et al., The European Union and Fishing Subsidies (2011), http://oceana.org/sites/ default/files/reports/EU_Subsidies_Report_FINAL_FINAL-1.pdf (accessed 8 May 2017) at 4-12; Al Jazeera, Anger as EU maintains fishing subsidies (2012), http://www.aljazeera.com/news/europe/2012/ 10/20121024111943401501.html (accessed 25 February 2017).

101 Young, supra note 60, at 87-88; ibid; Schrooer et al., supra note 100, at 3.

102 France, for example, has been found guilty of not complying with EU fishing laws by the European Court of Justice, regarding the size of drift nets (which net large numbers of by-catch), mesh sizes, and offering undersized fish for sale - see Case C-556/07, Commission of the European Communities v. French Republic [2009] ECR I-00025 (ECLI:EU:C:2009:133) and Case C-304/02, Commission of the European Communities v. French Republic [2005] ECR I-06263 (ECLI:EU:C:2004:274).

103 The University of British Colombia, An estimate of the total catch in the Spanish Mediterranean Sea and Gulf of Cadiz Regions (1950-2010) (2015), http://www.seaaroundus.org/doc/publications/wp/ 2015/Coll-et-al-Spain-Med-and-Gulf-of-Cadiz.pdf (accessed 25 February 2017) at 4, 6 and 21; K. Willson, M. Cabra, and M. G. Rey, 'Nearly €6 Billion in Subsidies Fuel Spain's Ravenous Fleet', Part II Looting the Seas (2012), https://www.icij.org/sites/icij/files/looting_the_seas.pdf (accessed 16 September 2017) 50 .

104 Willson et al., supra note 103.

105 Ibid.

$106 \mathrm{Al}$ Jazeera, supra note 100; G. Carpenter, The EU Common Fisheries Policy has helped, not harmed, UK fisheries (2016), https://www.opendemocracy.net/can-europe-make-it/griffin-carpenter/eu- 
stocks ${ }^{107}$ and, for the past few years, many of the Baltic States, including Denmark, Latvia and Germany, have also been allocated quotas above those advised by ICES. ${ }^{108}$

How does this conduct contravene the Chapeau? Clearly, the conduct of the EU is discriminatory if it applies different rules to its own fishers and those of third party countries, when these fishers are competing in the same market. ${ }^{109}$ But is this unjustifiable or arbitrary discrimination? If we accept that Panels and the Appellate Body look at the availability of less discriminatory measures when analysing this question, a potentially less discriminatory means of achieving the objectives of the EU Regulations would be to focus on eradicating IUU fishing in EU waters, before attempting to eradicate it in other countries. It is certainly arguable that the EU should focus its energy on this problem, and could do so by scrapping modernization subsidies and lowering quotas. The EU could hardly protest at such a finding, given that, in the IUU Regulation, the criteria for designating non-cooperating countries include "whether the third country concerned has taken effective enforcement measures in respect of the operators responsible for IUU fishing ... the history, nature, circumstances, extent and gravity of the manifestation of IUU fishing considered', 110 and 'any act or omission by the third country concerned that may have diminished the effectiveness of applicable laws, regulations or international conservation and management measures'. ${ }^{111}$ Similarly, in designating NSF countries under the Shared Stocks Regulation, the EU must consider whether the country has failed 'to cooperate in the management of a stock of common interest ... and either it fails to adopt necessary fishery management measures or it adopts fishery management measures without due regard to the rights, interests and duties of other countries and the Union, and those fishery management measures, when considered in conjunction with measures taken by other countries and the Union, lead to fishing activities which could result in the stock being in an unsustainable state'. ${ }^{112}$

However, a focus on IUU fishing in the EU alone may not be enough to achieve the legitimate objectives of the EU, which, as discussed, include protecting exhaustible natural resources under Article XX $(\mathrm{g})$, complying with multilateral treaties and bilateral agreements, and fulfilling an objective of general importance to WTO members.

common-fisheries-policy-has-helped-not-harmed-uk-fisheries-0 (accessed 25 February 2017); Willson, supra note 103 .

107 F. Harvey and A. Neslen, Fishing quotas defy scientists' advice (2014), https://www.theguardian. com/environment/2014/dec/16/fishing-quotas-defy-scientists-advice (accessed 25 February 2017).

108 G. Carpenter, Landing the Blame: Overfishing in the Baltic 2017 (2016), http://neweconomics.org/ wp-content/uploads/2016/12/NEF_LANDING-THE-BLAME-ECOPY.pdf (accessed 25 February 2017).

109 See Bartels, supra note 89, at 110-112.

110 IUU Regulation, supra note 3, art. 31(5)(c).

111 Ibid., art. 31(6)(c).

112 Shared Stocks Regulation, supra note 4, art. 3. 
(b) An effective alternative?. The EU has, in recent years, done much to build up its fish stocks to sustainable levels. It has scrapped boat-building subsidies, updated its Common Fisheries Policy to provide that quotas be set in line with scientific data, reformed the practice of discarding fish which is undersized, and required its members to come up with action plans to reduce overcapacity. ${ }^{113}$ It has promulgated laws to prevent its own nationals overfishing, and enforces these laws through cases brought to the European Court of Justice, including several cases against Spain, ${ }^{114}$ and has become a party to many multilateral agreements dealing with fisheries, including UNCLOS, UNFSA, the PSMA, and several RFMOs. ${ }^{115}$

Although fishing quotas are sometimes set higher for EU members than scientific evidence allows, these quotas in fact flout scientific advice less than those quotas negotiated with non-EU states, often because of the difficulty of keeping non-EU states at the negotiating table. ${ }^{116}$ In addition, some of the subsidies the EU provides go towards de-commissioning boats, retraining, development of aquaculture, and temporary cessation of fishing activities. ${ }^{117}$ Thus, while there are certainly grounds for criticism of the EU, as it still maintains certain capacity-enhancing subsidies, ${ }^{118}$ at least some of its subsidies are being used to promote sustainable fishing. These efforts at reform, although primarily aimed at undoing damage, suggest that the EU is attempting to control IUU fishing in its own waters, and will continue to do so in line with its international obligations under the RFMOs and other treaties to which it is a party.

The EU is also unusual in its geographical and political make-up and, thus, its difficulties in eradicating IUU fishing. The EU covers a large, densely populated area, making policing of IUU fishing difficult, although it is, admittedly, not unique in this regard. More significant for enforcement purposes are the difficulties produced by internal EU politics. The EU relies on its members to police fishing in EU waters, the same members that have been taken to court multiple times by the European Commission for violating EU fisheries laws. Pressure is applied by EU members, primarily Spain, France, and Portugal, to retain modernization subsidies. ${ }^{119}$ There is also constant pressure by the fishing industry to increase

113 K. Donnelly, SPICe Briefing: The Reformed Common Fisheries Policy (2014), http://www.parliament.scot/ResearchBriefingsAndFactsheets/S4/SB_14-49.pdf (accessed 25 February 2017), at 3-4.

114 See for examples of cases brought against Spain, Case C-189/07, Commission of the European Communities v. Kingdom of Spain [2009] ECR I-00195 (ECLI:EU:C:2008:760); Case C-42/03, Commission of the European Communities v. Kingdom of Spain, judgment of 2 December 2004, not yet reported (ECLI:EU:C:2004:764). For cases against France see Case C-556/07, supra note 102; Case C-304/02, supra note 102.

115 European Commission, Regional Fisheries Management Organizations (RFMOs) (2017), https:// ec.europa.eu/fisheries/cfp/international/rfmo_en (accessed 25 February 2017).

116 Carpenter, supra note 108.

117 Schroeer, supra note 100 , at 5.

118 Ibid. at 4-12; Al Jazeera, supra note 100.

119 Ibid. (Al Jazeera). 
quotas; in 2016, lobbyists from the Netherlands and Spain even used press passes to enter the EU Council building in Brussels during ministerial negotiations on fishing quotas so that they could advise and influence ministers. ${ }^{120}$ The EU's position is particularly precarious at the moment, with a poll prior to the Brexit vote suggesting that nine out of ten UK fishers supported Brexit because of job losses perceived to be caused by EU fishing policy, ${ }^{121}$ and threats by populist election candidates in a number of EU members to leave the EU should they be elected. ${ }^{122}$

This suggests that the EU is doing all it can to prevent IUU fishing in difficult political and geographical circumstances. A Panel pronouncing on the WTO-consistency of the EU Regulations could request further information to determine whether this is really the case. ${ }^{123}$ If this is true, however, declaring the EU Regulations WTO-inconsistent will only cause further harm to the environment, as there is no possibility of amending them. This appears contrary to the jurisprudence and practice of the WTO, the concerns about IUU fishing displayed by its Members, and international fisheries law.

The EU itself recognizes that circumstances prevailing in a country are important in deciding if a country complies with the EU Regulations. The EU does not require a non-cooperating country to completely eradicate IUU fishing in its waters before lifting a trade ban or withdrawing a warning. Indeed, the EU withdrew its warnings to Korea and the Philippines because they showed 'constructive cooperation' and 'made significant structural reforms in their fisheries management systems'. ${ }^{124}$ It is suggested that a similar approach be taken by Panels and the Appellate Body, given the difficulty of eradicating IUU fishing in circumstances such as those faced by the EU.

In addition, as Young has pointed out, IUU fishing must be tackled on many fronts for measures to be effective. ${ }^{125}$ Bjorge, too, in his writings on evolutionary interpretation, believes that a treaty's effectiveness is the central aspect of treaty interpretation, rather than the wording of the treaty. ${ }^{126}$ The Appellate Body in Brazil-Tyres, albeit while determining necessity under Article XX(b), also found that measures to tackle important health and environment problems may need to

120 Corporate Europe Observatory, Fishing for influence (2017), https://corporateeurope.org/powerlobbies/2017/05/fishing-influence (accessed 9 May 2015).

121 D. Vevers, Nine in Ten Fishermen Will Back Brexit, Survey Suggests (2016), https://stv.tv/news/ politics/1356963-nine-in-ten-fishermen-will-back-brexit-survey-suggests/ (accessed 25 February 2017).

122 Note, for example, the recent elections in the Netherlands and France, and upcoming election in Germany.

123 Article 13 of the DSU, supra note 9, allows a Panel to 'seek information and technical advice from any experts to obtain their opinion on certain aspects of the matter'. It is also possible that the Appellate Body could seek such information after US-Shrimp where the Appellate Body held that it may draw up its own working procedures, although this has been a controversial finding.

124 European Commission, supra note 40.

125 Young, supra note 78 , at 15.

126 E. Bjorge, The Evolutionary Interpretation of Treaties (Oxford University Press, 2014), at 190. 
be complementary to be effective. ${ }^{127}$ A Panel or Appellate Body should, therefore, take into account that the EU must tackle the problem of IUU fishing both within and without for these methods to be effective. This would allow the EU to comply with its international obligations for reasons that come directly from WTO jurisprudence.

\subsubsection{Lack of consultation with non-cooperating and NSF countries}

The EU cooperated extensively with trading partners and stakeholders in creating the EU Regulations and has entered into several international fisheries agreements, including RFMOs. For purposes of Faroes-Herring, it entered into a bilateral treaty with the Faroes to cooperate on fish stock conservation. ${ }^{128}$ All of this indicates a genuine effort on the part of the EU to conserve fish stocks through multilateral cooperation, but in Faroes-Herring, the EU did not attempt serious multilateral talks with the Faroes prior to imposing port state measures. This led to an allegation by the President of the Faroes that the EU refused to engage in talks after the Faroes set its unilateral quota, and instead strong-armed the Faroes into accepting the quota decided by the NEAFC parties by imposing unilateral trade measures. ${ }^{129}$ With regard to this allegation, however, it is suggested that the motives of a country are more appropriately dealt with under the final element of the Chapeau - whether the measure constitutes a disguised restriction on international trade. In determining unjustifiable or arbitrary discrimination, it is necessary only to consider whether greater multilateral cooperation with the Faroes, or a non-cooperating country should the situation arise, would have constituted a less discriminatory measure to achieve the EU's legitimate objectives.

(a) Multilateral cooperation to conserve fish stocks. Multilateral cooperation has been something of a theme in WTO cases involving the environment, and is also an important aspect of fisheries law. This makes sense, given that fish stocks, particularly migratory and straddling fish stocks, are a common resource that is best protected when countries work together to set quotas, police the seas, share information on vessels engaged in IUU fishing, and simultaneously close their ports to IUU fish to prevent the rise of ports of convenience. ${ }^{130}$

In US-Shrimp, the Appellate Body decided that the US had discriminated unjustifiably against the complainants because it had not engaged in multilateral cooperation with them prior to imposing the turtle ban. ${ }^{131}$ Although the Appellate Body in

127 Brazil-Tyres, supra note 81, para 172.

128 Council Regulation 2211/80, OJ 1980 L 226/12.

129 K. L. H. Johannesen, President of the Faroe Islands, Coercive Economic Measures Are Illegal and Counterproductive (2014), http://www.government.fo/news/news/government-of-the-faroes-coercive-economic-measures-are-illegal-and-counterproductive/ (accessed 25 February 2017).

130 Ports of convenience are those that allow fish caught by IUU means to enter, thereby undermining the efficacy of port state measures implemented by other states in the area.

131 US-Shrimp, supra note 18, para. 172. 
US-Shrimp 21.5 did state that unilateral measures are permissible in certain instances, ${ }^{132}$ unilateral measures have, thus far, not found favour with Panels and the Appellate Body in environmental cases. In US-Gasoline, for example, the Appellate Body found that the failure of the US to cooperate with Venezuela and Guatemala on administrative issues contravened the anti-discrimination provisions of the Chapeau. ${ }^{133}$ Even in EC-Seals, a case which was concerned with the prevention of cruelty to animals rather than the sharing of a common resource, the Appellate Body found that the EU's failure to pursue 'cooperative arrangements' with Canadian Inuit, as it had done with Greenlandic Inuit, contributed to the inconsistency of the seal regulations with the Chapeau. ${ }^{134}$

In the context of fisheries law (and environmental law in general), ${ }^{135}$ there are a number of treaties and cases that stress multilateral cooperation. UNCLOS obliges state parties to cooperate in the conservation of living resources, including shared resources and resources in the high seas. Under Articles 63(1) and (2) of UNCLOS, states must 'seek to agree' on conservation measures for shared stocks. ${ }^{136}$ Articles 63(1) and (2) are expanded on in UNFSA. ${ }^{137}$ The International Tribunal for the Law of the Sea (ITLOS), in its IUU Fishing Opinion, ${ }^{138}$ found that both UNCLOS and UNFSA place an obligation on parties to consult with each other to conserve fish stocks and, furthermore, give each party a right to consult in an RFMO. ${ }^{139}$ The findings in the IUU Fishing Opinion are reiterated in UNFSA. ${ }^{140}$ Many other international fishing instruments also advocate for cooperation and consultation in the creation of measures to conserve species. ${ }^{141}$

Young, too, has suggested that more be done in the multilateral arena to prevent IUU fishing. However, these measures, according to Young, should form part of an overall strategy to combat IUU fishing, including unilateral measures. ${ }^{142}$ O'Brien also argues that both multilateral cooperation and unilateral measures are needed to address environmental issues. As these issues have global effects, there

132 US-Shrimp 21.5, supra note 69, para. 203.

133 US-Gasoline, supra note 82, at 27.

134 WTO, EC-Measures Prohibiting the Importation and Marketing of Seal Products, 22 May 2014, WT/DS400/AB/R; WT/DS401/AB/R, paras. 5.337-5.338.

135 See M.A. Fitzmaurice, 'International Environmental Law as a Special Field', 25 Netherlands Yearbook of International Law (1994), 181, at 212.

136 UNCLOS, supra note 5.

137 UNFSA, supra note 43.

138 ITLOS, Request for an Advisory Opinion Submitted by the Sub-Regional Fisheries Commission, 2 April 2015, ITLOS Case No. 21.

139 Ibid., para. 205.

140 UNFSA, supra note 43, arts 5, 6 and 8.

141 Examples include the FAO Fisheries Code, supra note 44, arts 11.2.9 and 11.2.14; PSMA, supra note 15, art. 6; IPOA-IUU, supra note 24, ss 9.1 and 68; Agreement to Promote Compliance with International Conservation and Management Measures by Fishing Vessels on the High Seas 1993, 2221 UNTS 120, art. 5 .

142 Young, supra note 78 , at 15. 
is, according to O'Brien, 'a national obligation' to ensure that conservation or preservation measures are put in place, including those that influence policy in other states. ${ }^{143}$ Measures effecting policy changes in other countries are permissible under Article XX after US-Shrimp. ${ }^{144}$

The use of both multilateral and unilateral measures does seem to be the most effective means of dealing with many environmental problems. States are not always willing to cooperate, particularly when cooperation would go against their immediate developmental and fiscal interests. Even where international agreements require only best efforts to cooperate, as is the case in both fisheries and trade law, it can still be a time-consuming process to entreat countries to enter into multilateral talks. The EU's difficulties negotiating with non-member countries, and the concomitant effects of quotas higher than those recommended by scientific evidence, have already been touched on. Indeed, the emphasis on multilateral cooperation in US-Shrimp is actually seen by some as anti-environment, given that conservation measures must often be taken urgently to prevent irreversible damage while multilateral solutions may take years to reach. ${ }^{145}$

For these reasons, it is suggested that there is a need for both unilateral and multilateral measures to combat IUU fishing. This should be taken into account in determining whether multilateral cooperation is really a less discriminatory measure, or simply a complementary one. Naturally, this would open the door for similar arguments to be made in cases involving other environmental problems. If there is a need to differentiate, it is suggested that urgency should be the means of drawing a line between those cases where unilateral measures are allowed and those in which they are not. This would allow room for WTO members to take action to protect the environment in a meaningful way, and answer the anti-environment criticism levelled at the WTO after US-Shrimp, while giving Panels and the Appellate Body the means to balance trade and environment concerns in an appropriate manner. The problem of IUU fishing undoubtedly meets a requirement of urgency. It is not a problem that can be allowed to wait for years while compromise is reached. Many fish stocks are already severely overfished, some beyond hope of recovery. ${ }^{146}$ This is due in large part to IUU fishing, which undermines the ability of

143 P. O’Brien, 'Unilateral Environmental Measures after the WTO Appellate Body's Shrimp-Turtle Decision', in E. Weiss, J. H. Jackson, and N. Bernasconi-Osterwalder (eds.), Reconciling Trade and Environment (Martinus Nijhoff Publishers, 2008), 451, at 451.

144 US-Shrimp, supra note 18 , at 121.

145 Ibid., at 475-476; R. Benedini, 'Complying with the WTO Shrimp-Turtle Decision', in E. Weiss, J. H. Jackson and N. Bernasconi-Osterwalder (eds.), Reconciling Trade and Environment (2008) 419, at 442; C. Wold and G. Fullilove, Analysis of the WTO Appellate Body's Decision in Shrimp/Turtle (2000), http://law.lclark.edu/clinics/international_environmental_law_project/our_work/trade_and_environment/ turtle_briefing.php (accessed 25 February 2017).

146 FAO, The State of World Fisheries and Aquaculture (2016), http://www.fao.org/3/a-i5555e.pdf, (accessed 8 May 2017), at 5-6. 
states to manage stocks at sustainable levels, and causes severe environmental damage and economic loss, particularly for developing countries. ${ }^{147}$

Of course, determining whether a problem is urgent does require a type of value judgment by Panels and the Appellate Body, which could lay them open to criticism and require a departure from their consistent narrative that their sole function is to interpret WTO agreements, not pronounce on the legitimacy of member's policy objectives. Although it is arguable that Panels and Appellate Bodies already undertake these sorts of value judgments under the Chapeau, ${ }^{148}$ there are also ways that a Panel or Appellate Body could utilize past jurisprudence to avoid this issue altogether. Trebilcock et al, for example, see multilateral cooperation as unnecessary where a measure is sufficiently flexible to take account of different situations in different countries. ${ }^{149}$ O'Brien also speculates that 'the failure to pursue multilateral negotiations may not render a measure in violation of Article XX if such failure did not result in a harmful discrimination to exporting members (if, for example, exporting member concerns were addressed in administrative practice).' ${ }^{150}$ These interpretations suggest that a lack of multilateral cooperation may not be enough for a finding of WTO-inconsistency, particularly with regard to the EU Regulations, which are both flexible and administratively fair. In a similar vein, Briggs suggests that the judgments in US-Gasoline and US-Shrimp created a 'sliding-scale' test whereby the greater the discriminatory effect on international trade, the greater the requirement of multilateral cooperation. ${ }^{151}$ As the EU Regulations provide for a range of measures to be imposed in different circumstances, cases where the measures are not particularly trade-restrictive may be subject to less scrutiny if this theory is applied, although this does not assist in the case of Faroes-Herring, which dealt with an import ban.

(b) Multilateral cooperation in the EU. In addition to these possibilities, in the case of the EU Regulations, there is a further compelling reason not to find multilateral cooperation to be an alternative, less discriminatory measure - namely, the amount of multilateral cooperation the EU has already engaged in when it comes to port state measures, preventing IUU fishing, and fish stock sustainability. This includes the many multilateral treaties, RFMOs, and bilateral treaties to which the EU is a party, as well as its approval, in the EU Regulations, of soft law

147 Agnew, supra note 28.

148 See, e.g., WTO, Korea-Measures Affecting Imports of Fresh, Chilled and Frozen Beef, 10 January 2001, WT/DS161/AB/R; WT/DS169/AB/R, para. 162; where the Appellate Body, in the context of necessity in Article $\mathrm{XX}(\mathrm{b})$ found that ' $[\mathrm{t}]$ he more vital or important [the] common interests or values are, the easier it would be to accept as "necessary" a measure designed as an enforcement instrument,' The Appellate Body repeated this statement in EC-Asbestos, supra note 81, para. 172.

149 M. Trebilcock, R. Howse, and A. Eliason, The Regulation of International Trade (2013) at 678. 150 O'Brien, supra note 143 , at 471.

151 Briggs, supra note 89 , at 293-294. 
instruments dealing with fishing, such as the IPOA-IUU. ${ }^{152}$ The EU's warnings to non-cooperating countries under the IUU regulation, and attempts to assist these countries to combat IUU fishing, ${ }^{153}$ is further evidence that the EU cooperates with countries to fix problems prior to imposing trade measures.

In US-Shrimp, the Appellate Body highlighted the failure of the US to enter into various multilateral treaties, under which it could have cooperated to conserve sea turtles, in analysing whether the turtle regulations complied with the Chapeau. ${ }^{154}$ In addition, the Appellate Body took the view that, in interpreting the Chapeau, it was marking a line of equilibrium between the right of a member to invoke an Article XX exception and the rights of the other WTO members under substantive provisions of the GATT. ${ }^{155}$ For the Appellate Body, the Inter-American Convention for the Protection of Sea Turtles 'marked the equilibrium line' between 'the right of a Member to invoke an exception under Article XX and the rights of the other Members under varying substantive provisions (e.g., Article XI) of the GATT 1994', and showed that countries could come to a solution on the issue of sea turtle conservation through multilateral cooperation. ${ }^{156}$ Thus, the Appellate Body does not appear to require cooperation beyond entering into an agreement such as an RFMO, or bilateral agreements to conserve the species at issue in the case. An interpretation requiring something more, therefore, seems unnecessary in the case of the EU Regulations.

However, it is suggested that membership of an RFMO, or bilateral treaty by the parties to a case, may not even be a necessary pre-condition to a finding of multilateral cooperation in a case involving port state measures. This is not such a radical proposition if we consider that international fisheries law is, in large part, made up of soft law instruments like the FAO Fisheries Code and IPOA-IUU, which cannot have parties but have received wide support and approbation, and if we consider the commitments that WTO members have made to fisheries sustainability, including negotiations on fisheries subsidies, and the concern for fisheries displayed by those WTO members which negotiated the TPP. In practice, too, Panels and the Appellate Body take into account non-WTO agreements to inform their decisions, even when the parties to the dispute are not parties to these agreements, as discussed in Section 3. As Peters points out, Article 31 of the VCLT, which is referred to often by Panels and Appellate Bodies as a codification of international law, arguably 'allows and even mandates treaty-interpreters to take into account ... not only treaty norms but also customary norms and possibly even soft law'.157

152 See IUU Regulation, supra note 3, Preamble 4.

153 European Commission, supra note 40.

154 US-Shrimp, supra note 18, para. 171.

155 Ibid., para. 159.

156 Ibid., para. 170.

157 Peters, supra note 74, at 1025 . 
(c) Disguised Restrictions. In 2014, the Prime Minister of the Faroes, in a statement on Faroes-Herring, alleged that the EU was using its measures to impose a management arrangement for herring on the other states 'which it alone considers to be equitable'. ${ }^{158}$ Allegations of protectionism were also levelled against the EU by a former MP of Thailand's Democratic Party after Thailand was issued a yellow card under the IUU Regulation. ${ }^{159}$ These statements are blatantly not objective evidence of an improper purpose and, in the case of the Faroes statement, clearly untrue, as the other NEAFC members did come to an allocation agreement in its absence, rather than the EU simply imposing what it deemed to be a fair allocation. However, these allegations do indicate that the second element of the Chapeau may be raised in cases involving the EU Regulations.

There has been very little case law on what constitutes a disguised restriction on international trade. In US-Gasoline, the Appellate Body found that the gasoline regulations alleviated certain costs for domestic but not foreign gasoline producers, which suggested a disguised restriction. ${ }^{160}$ Its reasoning suggests that this element of the Chapeau is designed to prevent protectionism. Within the EU, demand for fish surpasses its fishing capacity, and the EU is dependent on imports from third countries to meet local demand. ${ }^{161}$ The purpose of the EU Regulations is, thus, unlikely to be protectionist. However, Bartels believes that this element of the Chapeau goes beyond protectionism and applies when measures with a seemingly legitimate purpose are adopted for an illegitimate purpose, like protectionism. This gives rise to the question of whether the illegitimate purpose must be the primary purpose, or simply a purpose, no matter how minor. ${ }^{162}$ This is an important issue. Another is how a Panel or Appellate Body would determine the weight to be given to each purpose. Presumably, this would require a subjective assessment of lawmaker's intentions, gleaned from objective facts.

There is the danger of a disguised motive, such as protection of quota allocations, in circumstances where the EU imposes measures on countries like the Faroes, with which it is negotiating quotas. Even if evidence of such motive could be found, however, the EU's ongoing commitment to preventing IUU fishing, discussed above, suggests that this would be only one purpose of imposing the measure. A Panel or Appellate Body would then have to decide if this motive was the principal motive and, if not, whether a subsidiary motive would be enough to declare the EU Regulations inconsistent with the Chapeau.

158 Johannesen, supra note 129.

159 P. Rojanaphruk, EU's motive behind yellow card queried (2015), http://www.biothai.org/news/ 650 (accessed 9 May 2017).

160 US-Gasoline, supra note 82 , at 28-29.

161 House of Ocean, The US, the EU and IUU-Part 2 (2015), https://houseofocean.org/2015/05/17/ the-us-the-eu-and-iuu-part-2/ (accessed 25 February 2017); Schroeer, supra note 100, at 3.

162 Bartels, supra note 89 , at 123. 
The deep infringement on regulatory autonomy of allowing a subsidiary motive to be grounds for non-compliance should perhaps be reason enough not to follow such a course. While a state's traditional 'Westphalian' sovereignty is no longer an absolute in today's globalized world, state sovereignty remains an important principle in international law, particularly in a member-driven organization like the WTO. In US-Shrimp, the Appellate Body also made it clear that the right to take measures under Article XX should be balanced against the rights of members under the substantive provisions of the GATT. ${ }^{163}$ Allowing a subsidiary purpose to invalidate a measure appears to upset this balance and give more protection to members' rights under the substantive provisions than their right to take measures under the Chapeau. It is suggested, therefore, that where the primary purpose of a measure is legitimate, especially where many WTO members have expressed a concern for such a purpose, as has occurred in the case of IUU fishing, a less laudable subsidiary purpose should not lead to a finding of WTOinconsistency, provided that no less trade-restrictive measure is available to achieve the primary purpose.

\section{Conclusion}

Increasing use of port state measures to prevent IUU fishing raises a number of interesting questions on the relationship between international trade and fisheries law. The growing number of agreements and soft law instruments attempting to prevent IUU fishing, and thereby alleviate some of the pressure on a diminishing resource, illustrate the importance of this issue to the international community. However, aspects of these instruments, particularly those dealing with port state measures, may conflict with WTO law. This paper has suggested that use of conflict presumptions, particularly inter se agreements, may be a way to resolve such conflict. However, Panels and the Appellate Body are more likely to try and reconcile international trade and fisheries law, and may not allow use of inter se agreements at all after Peru-Agricultural Products.

This paper took Faroes-Herring and non-cooperating countries as a study, to illustrate ways in which international trade and fisheries law can be reconciled when determining WTO-compliance of domestic regulations - in this case the EU Regulations - which impose port state measures for IUU fishing. It found that, while the EU Regulations are well crafted, they could fail to be defended under the GATT Article XX Chapeau because of the difficulties that the EU faces, both in preventing its own nationals from engaging in IUU fishing, and in engaging third party states in negotiations. While much of the blame for the IUU fishing in EU members may be laid at the EU's own door, justice in this case comes at a cost. Many fish species are dangerously close to stock collapse, largely because 
IUU fishing undermines attempts to keep fishing at sustainable levels, and the EU Regulations have been successful in forcing a number of third party states to cut down on IUU fishing in their waters.

Ideally, a WTO member should ensure that it engages properly with other WTO members before imposing unilateral measures against them, and prevent IUU fishing in its own waters, to the same extent as it does in third party states. However, this is not always possible. Preventing IUU fishing by its own members is a particular problem for the EU, which has to deal with difficult internal politics, and relies on the same members with which it has problems to police its waters.

The EU has also been reforming its own fisheries policies for a number of years. The EU's efforts to prevent IUU fishing, and move towards reform of IUU fishing practices show a real commitment to eradicating IUU fishing, but they can only be effective in conjunction with measures that apply outside the EU. Multilateral measures are important, but unilateral measures should also be a part of the solution. It should also be recognized that a finding of WTO-inconsistency in the case of the EU Regulations might have little purpose but to cause environmental degradation, and create a conflict between international fisheries and trade law.

It is also suggested that while multilateral measures are important and should be pursued, in the case of port state measures to prevent IUU fishing they should not be seen as an alternative solution but rather part of a cumulative solution. This is particularly true where extreme environmental degradation may occur if a member has to spend years on multilateral talks without being able to maintain unilateral measures simultaneously. Of course, these measures should not be used as leverage to force multilateral solutions, but if this is the sole or primary purpose of enacting them, this can be dealt with under the inquiry into whether there is a disguised restriction on international trade. Past WTO jurisprudence also suggests that a requirement of multilateral cooperation can be dispensed with if the parties have entered into multilateral agreements dealing generally with the environmental concern, and particularly if an agreement includes the parties to the dispute and deals with the particular environmental concern at issue in the dispute. Because of the nature of international fisheries law, however, multilateral cooperation could also be seen to have occurred simply because of the wide support of WTO members and the international community for fisheries reform and soft law fisheries instruments, which require use of port state measures to prevent IUU fishing.

WTO jurisprudence and practice gives a Panel or Appellate Body a justification for these types of findings in a case like Faroes-Herring or a case brought by a noncooperating country against the EU. Cases such as US-Gasoline, US-Shrimp, and EC-Civil Aircraft show a definite move away from the trade-centric findings of previous Panels, such as those in the GATT-era US-Tuna cases, and a greater balancing of international trade and environmental law, while negotiations on fisheries subsidies in the Doha Round and the insertion of fisheries provisions in the TPP show that WTO members are concerned about fishing issues. Furthermore, the 
use of unilateral measures and cumulative measures to protect the environment, recognition of international agreements as multilateral solutions, and a certain amount of deference to regulatory autonomy are fully supported by WTO jurisprudence. Of course, certain of the suggestions in this paper, such as using urgency to determine when unilateral measures should be permitted, may require Panels and the Appellate Body to take a bolder interpretation of WTO jurisprudence and practice. It is suggested that, in the case of IUU fishing, this is worth doing to preserve our oceans for future trade. 